\title{
Molecular and serological detection and of Toxoplasma gondii in small ruminants of southwest Iran and the potential risks for consumers
}

\author{
Amin Yousefvand ${ }^{1,4} \cdot$ Seyed Ali Mirhosseini ${ }^{1}$ (1) $\cdot$ Masoud Ghorbani ${ }^{2} \cdot$ Tahereh Mohammadzadeh $^{3}$. \\ Mehrdad Moosazadeh Moghaddam ${ }^{2}$. Shirin Mohammadyari ${ }^{4}$
}

Received: 4 May 2020 / Revised: 16 October 2020 / Accepted: 23 October 2020 / Published online: 2 January 2021

(c) Bundesamt für Verbraucherschutz und Lebensmittelsicherheit (BVL) 2021

\begin{abstract}
Toxoplasmosis is one of the most important zoonotic diseases with serious health risks for humans, especially for immunodeficient patients, and can lead to abortion in pregnant women worldwide. The oral uptake of sporulated oocysts and/or consumption of undercooked/raw meat of animals infected with Toxoplasma gondii can infect other animals and humans. Heart, liver, and meat tissues of 150 sheep and 150 goats from a slaughterhouse in Ahvaz, Iran, were collected during autumn 2018 and analyzed via polymerase chain reaction (PCR) to detect parasitic DNA in the animal tissues. Moreover, antibodies against $T$. gondii of 150 sera samples were detected as the targets by in-house enzyme-linked immunosorbent assay (in-house ELISA). A total of $26(17.3 \%), 33(22 \%)$, and $48(32 \%)$ of liver, meat, and heart samples in sheep, and a total of $24(16 \%), 26(17.3 \%)$, and 36 (24\%) of liver, meat, and heart samples in goats, respectively, showed positive PCR results. Besides, the ELISA evaluation of sera samples from 150 sheep and 150 goats resulted in $26(13.3 \%)$ and $16(10.6 \%)$ positive cases, respectively. A significant difference was also found between PCR-positive heart samples and ELISA-positive sera samples of both animal species $(\mathrm{p}<0.05)$, but no significant difference existed between PCR-positive liver samples and ELISA-positive sera samples of both species $(\mathrm{p}>0.05)$. The results of this study confirm the presence of $T$. gondii in sheep and goats' consumable organs, highlighting the need to avoid consuming raw or uncooked organs of these animal species to prevent human infection with $T$. gondii.
\end{abstract}

Keywords Toxoplasma gondii $\cdot$ PCR $\cdot$ Serological study $\cdot$ Sheep $\cdot$ Goat

Electronic supplementary material The online version of this article (https://doi.org/10.1007/s00003-020-01306-w) contains supplementary material, which is available to authorized users.

Seyed Ali Mirhosseini

ali.mirh@gmail.com

Masoud Ghorbani

dr.ghorbani62@yahoo.com

1 Applied Microbiology Research Center, Systems Biology and Poisonings Institute, Baqiatallah University of Medical Sciences, Tehran, Iran

2 Applied Biotechnology Research Center, Baqiyatallah University of Medical Sciences, Tehran, Iran

3 Health Research Center, Life Style Institute, Baqiyatallah University of Medical Sciences, Tehran, Iran

4 Department of Food Hygiene, Faculty of Veterinary Medicine, Shahid Chamran University of Ahvaz, Ahvaz, Iran

\section{Introduction}

Toxoplasmosis, a zoonotic disease, is caused by obligate intracellular parasitic protozoa, $T$. gondii, leading to various clinical symptoms including encephalitis, chorioretinitis, mental retardation, loss of vision in congenitally-infected children and abortion in livestock (Tilahun et al. 2018; Abdallah et al. 2019; Shaapan 2016). The prevalence of $T$. gondii in different regions of the world varies from 0 to 100\% (Andreoletti et al. 2007a; Tenter et al. 2000) with serious consequences including treatment-related costs, morbidity, and mortality in vulnerable groups. Consumption of raw or undercooked animal meat is known to be one of the major risk factors for T. gondii infection (Andreoletti et al. 2007b). Felids, including domestic cats, are the definitive hosts, in which the parasitic protozoa complete their life cycle and pass the oocysts during defecation (Webster et al. 2013). In addition to vertical transport (i.e., mother to fetus), the parasite can infect humans and different animals horizontally 
when sporulated oocysts are taken up by consuming contaminated raw vegetables, water and/or undercooked or raw animal meat containing $T$. gondii tissue cysts (Dubey 2008). However, as the parasite cysts are only microscopically observed, they are undetected during meat inspection, thus, the infection enters the human food chain via raw or undercooked meat and liver of warm-blooded animals such as sheep and goats, as the main reservoir of $T$. gondii (Shapiro et al. 2019).

Several studies have reported that one-third of the world's adult population have been already infected with $T$. gondii (Saki et al. 2018). The overall seroprevalence rate of $T$. gondii among Iranian general population is reported to be around 39.9\% (Daryani et al.2014). In turn, the prevalence rate of $T$. gondii infection in sheep and goats has been estimated ranging from 10 to $38 \%$ in Iran (Table 1).

Based on the results of previous studies, the prevalence of $T$. gondii in sheep and goats is more prominent in some countries because the pastures therein are more exposed to T. gondii oocysts (Shapiro et al. 2019; Dubey 2009), making the parasite a common infectious agent among the animals of these regions (Dubey 2009; Jittapalapong et al. 2005).

An earlier epidemiological study with geographical conditions similar to that in the present study has demonstrated that the T. gondii-IgG antibody was detected in $12.2 \%$ of the sheep and $4.4 \%$ of the goat samples in Kashan, Iran (Rasti et al. 2017). The main seroprevalence studies reported in Iran are summarized in Table 1 . In other countries, the seroprevalence of $T$. gondii in sheep and goats have been reported to be $31.01 \%$ and $17.11 \%$ in Egypt (Mahboub et al. 2013), 26.2\% and 42.8\% in Pakistan (Ahmed et al. 2016), $33 \%$ and $27 \%$ in Ghana (Van der Puije et al. 2000), respectively. In addition, the seroprevalence of $T$. gondii in sheep was found to be $56.0 \%$ in Finland (Katzer et al. 2011). According to the aforementioned studies, the prevalence of T. gondii varies in different countries hypothetically due to

Table 1 A snapshot on the prevalence of $T$. gondii in sheep and goats in Iran

\begin{tabular}{|c|c|c|c|c|}
\hline Location & Animals & Serology & PCR & References \\
\hline Qazvin Province, North of Iran & Sheep & ELISA, $33.62 \%$ & - & Izadyar et al. (2019) \\
\hline Qazvin Province, North of Iran & Goat & ELISA, $36.41 \%$ & - & Izadyar et al. (2019) \\
\hline Gilan Province, North of Iran & Sheep & Dye Test, $36.8 \%$ & - & Havakhah et al. (2014) \\
\hline Gilan Province, North of Iran & Goat & Dye test, $12.9 \%$ & - & Havakhah et al. (2014) \\
\hline $\begin{array}{l}\text { Mazandaran province, North of } \\
\text { Iran }\end{array}$ & Sheep & IFAT, 30\% & - & Sharif et al. (2007) \\
\hline $\begin{array}{l}\text { Mazandaran province, North of } \\
\text { Iran }\end{array}$ & Goat & IFAT, $35 \%$ & - & Sharif et al. (2007) \\
\hline Kashan, Center of Iran & Sheep & ELISA, $12.2 \%$ & Heart, $17.8 \%$ & Rasti et al. (2017) \\
\hline Kashan, Center of Iran & Goat & ELISA, $4.4 \%$ & Heart, $8.9 \%$ & Rasti et al. (2017) \\
\hline Kerman, Southeastern Iran & Sheep & IFAT, $3.3 \%$ & - & Derakhshan and Mousavi (2014) \\
\hline Kerman, Southeastern Iran & Goat & IFAT, $1.7 \%$ & - & Derakhshan and Mousavi (2014) \\
\hline $\begin{array}{l}\text { Khuzestan province, South-West } \\
\text { of Iran }\end{array}$ & Sheep & $\begin{array}{l}\text { ELISA, liver juice serology, } \\
32.6 \%\end{array}$ & Liver, $8 \%$ & Bahrami et al. (2019) \\
\hline $\begin{array}{l}\text { Khuzestan province, South-West } \\
\text { of Iran }\end{array}$ & Goat & ELISA, liver juice serology, $48 \%$ & Liver, $11.3 \%$ & Bahrami et al. (2019) \\
\hline $\begin{array}{l}\text { Khuzestan province, South-West } \\
\text { of Iran }\end{array}$ & Sheep & - & Meat, $14 \%$ & Rahdar et al. (2014) \\
\hline $\begin{array}{l}\text { Chaharmahal and Bakhtiari, } \\
\text { South-West of Iran }\end{array}$ & Sheep & - & $\begin{array}{l}\text { Tongue, brain, femur muscle } \\
\text { and liver, } 38 \%\end{array}$ & Azizi et al. (2014) \\
\hline Jahrom, south of Iran & Sheep & ELISA, $35.94 \%$ & Heart and diaphragm, $34.32 \%$ & Armand et al. (2016) \\
\hline Kerman, Southeastern Iran & Sheep & - & $\begin{array}{l}\text { Diaphragm, } 27.5 \% \\
\text { Heart, } 52.5 \% \\
\text { Brain, } 90 \%\end{array}$ & Tavakoli Kareshk et al. (2017) \\
\hline Kerman, Southeastern Iran & Goat & - & $\begin{array}{l}\text { Diaphragm, 50\% } \\
\text { Heart, 22\% } \\
\text { Brain, 55\% }\end{array}$ & Tavakoli Kareshk et al. (2017) \\
\hline $\begin{array}{l}\text { Khuzestan province, South-West } \\
\text { of Iran }\end{array}$ & Sheep & ELISA, $13.3 \%$ & $\begin{array}{l}\text { Heart, 32\% } \\
\text { Meat, } 22 \% \\
\text { Liver, } 17.3 \%\end{array}$ & Current study \\
\hline $\begin{array}{l}\text { Khuzestan province, South-West } \\
\text { of Iran }\end{array}$ & Goat & ELISA, $10.6 \%$ & $\begin{array}{l}\text { Heart, } 24 \% \\
\text { Meat, } 17.3 \% \\
\text { Liver, } 16 \%\end{array}$ & Current study \\
\hline
\end{tabular}


climate and cultural diversity in each region. For example, a considerable risk factor of toxoplasmosis in Iran is the consumption of raw or semi-cooked liver of warm-blooded animals such as sheep and goats as a treatment for iron deficiency, especially by pregnant women, deeming to be nourishing in cases of pregnancy or general lethargy mainly due to some traditional beliefs. This consumption pattern may result in toxoplasmosis disease (Hajimohammadi et al. 2017; Bahrami et al. 2019).

Toxoplasmosis is conventionally diagnosed by parasite isolation from biopsy material, which is not cost-effective and timesaving for large scale detection of the parasite, usually taking 6 weeks to detect parasitic DNA in the animal tissues. Accordingly, molecular and serological methods have been suggested to substitute the earlier detection techniques (Bahrami et al. 2019; Liu et al. 2015).

Given the severe consequences of infection with $T$. gondii, the present study aimed to evaluate $T$. gondii-IgG antibodies in blood and DNA samples of warm-blooded animals such as sheep and goats consumed by humans. To that end, heart, liver, and meat tissues of 150 sheep and 150 goats slaughtered in Ahvaz for human consumption were collected during autumn 2018 and analyzed using PCR to detect parasitic DNA in the animal tissues.

\section{Materials and methods}

\subsection{Sample collection}

The sample size was calculated by the statistical formula presented by Naing et al. (2006). The prevalence estimation was made based on the previous article that had reported the prevalence of $T$. gondii in sheep (serology: $32.6 \%$ and PCR: $8 \%$ ) and goats (serology: $48 \%$ and PCR: $11.3 \%$ ) in Iran (Bahrami et al. 2019). For the purpose of this study, a slaughterhouse in the southwestern part of Iran (Ahvaz, Khuzestan province) was visited eight times, once a week during autumn 2018, by the researchers to collect blood samples from the common carotid arteries of a total of 150 sheep and 150 goats using a $10-\mathrm{mL}$ vacutainer tube immediately after bleeding. The blood samples were then centrifuged at $4000 \mathrm{rpm}$ for $5 \mathrm{~min}$, and sera samples were separated and stored at $-20{ }^{\circ} \mathrm{C}$ for later serologic evaluation. Immediately after blood sampling from the slaughtered animals, their carcasses were opened and samples of blood, heart, liver, and meat (femur musculature) tissues were taken from 150 sheep ( 75 males and 75 females) and 150 goats ( 75 males and 75 females) using sterile single-use surgical blades and a 2-g piece of each tissue sample was then transferred into sterile plastic bags. The animals used were from eleven different farms which were randomly selected from the same slaughterhouse for the purpose of this study.

\subsection{Serological test}

Blood sera were tested for the presence of anti- $T$. gondii $\operatorname{IgG}$ antibodies, using an in-house ELISA in flat-bottom 96-well microplates as previously described (Bahrami et al. 2019).

The microplates (Greiner, Germany) were coated with $50 \mu \mathrm{L}$ of tachyzoite antigen of $T$. gondii $\mathrm{RH}$ strain (Razi institute, Iran), diluted in carbonate buffer (Sigma-Aldrich), pH 9.6 (1:50), and incubated overnight at $4{ }^{\circ} \mathrm{C}$. The excess antigen was removed by washing the microplates with phosphate buffered saline (PBS) (Sigma-Aldrich). Blocking was then performed with blocking buffer (5\% skimmed milk) for $60 \mathrm{~min}$ at $37^{\circ} \mathrm{C}$. Having washed the microplates, we added $100 \mu \mathrm{L}$ of sera (1:100 in PBS with Tween 20 or PBST) and the microplates were then incubated for $120 \mathrm{~min}$ at $37^{\circ} \mathrm{C}$. The wells were washed again as above, then $50 \mu \mathrm{L}$ of alkaline phosphatase-labeled anti-goat/sheep conjugate (Sigma-Aldrich) was added (1:500 in PBST) and incubated for $60 \mathrm{~min}$ at $37^{\circ} \mathrm{C}$. Once the micrplates were washed, 50 $\mu \mathrm{L}$ of substrate solution $(10 \mathrm{mg} / \mathrm{mL}$ 4-nitrophenyl phosphate in $10 \mathrm{~mL}$ diethanolamine buffer, $\mathrm{pH} 9.6$ ) was added and the microplates were incubated for $30 \mathrm{~min}$ at room temperature. The reaction was stopped with $50 \mu \mathrm{L}$ of hydrochloric acid (20\%). Negative control was obtained from a new-born sheep. After gaining the approval of the local ethics committee for the study protocol, the sheep were infected by a two-step intramuscular and subdermal injection of live tachyzoites to obtain a positive control sample. The sensitivity and specificity of this in-house ELISA test were $90.1 \%$ and $85.9 \%$, respectively. The absorbance was read at $450 \mathrm{~nm}$ after 30 min using an automatic microplate reader (ELX800Biotek, Biotek). The cut-off of optical densities (OD) was calculated using the method of Hillyer et al. (1992) including the mean OD of negative control sera plus two standard deviations.

\subsection{PCR amplification}

For DNA extraction, 200-250 mg of each tissue sample was digested in $200 \mu \mathrm{L}$ of lysis buffer [containing $100 \mathrm{mM}$ Tris-HCl, $200 \mathrm{mM} \mathrm{NaCl}, 0.1 \%$ sodium dodecyl sulfate (SDS), $1 \%$ Triton $\mathrm{X}-100$, and $5 \mathrm{mM}$ ethylenediaminetetraacetic acid (EDTA), pH 8.0 (Cinnagen, Iran)] plus $5 \mu \mathrm{L}$ of proteinase $\mathrm{K}[20 \mathrm{mg} / \mathrm{mL}$ (Cinnagen, Iran)] and incubated at $55{ }^{\circ} \mathrm{C}$ for $2 \mathrm{~h}$. The microtubes containing these contents were then mixed and transferred to a $100{ }^{\circ} \mathrm{C}$ water bath for $10 \mathrm{~min}$. Afterwards, the resulting solution was mixed again, centrifuged at $12,000 \mathrm{rpm}$ for $10 \mathrm{~min}$, and $200 \mu \mathrm{L}$ of supernatant was utilized for DNA extraction using a phenol-chloroform-isoamyl alcohol (25:24:1, V/V/V) method. Tissues of non-infected sheep were included as negative controls of DNA extraction. Also, tissue from a known infected animal was used as a positive control. 
DNA was subsequently used as the template in PCR (TC24/H(B), BYQ6041E-366, Bioer, China) for the amplification of a fragment of the B1 gene using 5'-GAGACCGCG GAGCCGAAGTGC-3' and 5'-CCTCCTCCTCCCTTC GTCCAAG-3' sequences as forward and reverse primers, respectively (Jalal et al. 2004), yielding a 469 bp product. PCR was carried out in the final volume of $25 \mu \mathrm{L}$ containing $12.5 \mu \mathrm{L}$ Taq DNA polymerase master mix Red (Amplicon, Denmark), $1 \mu \mathrm{M}$ of each primer, and $50 \mathrm{ng}$ DNA templates under the following conditions: $3 \mathrm{~min}$ at $94{ }^{\circ} \mathrm{C}$ as an initial denaturation step, followed by 30 cycles of denaturation at $94{ }^{\circ} \mathrm{C}$ for $45 \mathrm{~s}$, annealing at $52{ }^{\circ} \mathrm{C}$ for $45 \mathrm{~s}$, and extension at $72{ }^{\circ} \mathrm{C}$ for $60 \mathrm{~s}$. This was followed by a final extension at $72{ }^{\circ} \mathrm{C}$ for $5 \mathrm{~min}$. A negative control consisting of the reaction mixture and $2 \mu \mathrm{L}$ of DNase/RNase-free water instead of template DNA as well as a positive control consisting of DNA from the $T$. gondii tachyzoites (RH strain) were included in the PCR reactions. The amplification products were then analyzed by electrophoresis in ethidium bromide-stained $1.5 \%$ agarose gel prepared in Tris acetate EDTA (TAE) buffered medium (65 mM Tris- $\mathrm{HCl}, 22.5 \mathrm{mM}$ boric acid, 1.25 mM EDTA, pH 8.3), and subsequently were visualized using a UV trans-illuminator (UVitec, Cambridge, UK).

\subsection{Statistical analysis}

All statistical analyses were carried out using SPSS (Version 16.0, SPSS Inc., Chicago, USA). The association between gender and infection was analyzed by the Chi-square test. A $p$ value of $\leq 0.05$ was considered to indicate statistically significant differences. The McNemar test was, in turn, performed to compare PCR and ELISA results. Moreover, the agreement between ELISA and PCR was assessed by the calculation of Kappa statistic (Cohen's kappa coefficient or $\kappa$ ). The strength of agreement based on $\kappa$ was judged according to the following guidelines: $\kappa \leq 0.20$ without consistency, $0.21 \leq \kappa \leq 0.40$ poor agreement, $0.41 \leq \kappa \leq 0.60$ moderate agreement, $0.61 \leq \kappa \leq 0.80$ good agreement, $\kappa>0.80$ very good agreement (Petrie and Watson 1999).

\section{Results}

The prevalence of $T$. gondii was examined in samples of blood, liver, meat, and heart tissues from 150 sheep and 150 goats as follows.

\subsection{Serological and molecular evaluation in sheep}

A total of $26[17.3 \%, 95 \%$ confidence interval (CI) 14.3-20.4\%], 33 (22\%, 95\% CI 19.8-24.3\%), and 48 (32\%, 95\% CI 27.3-36.9\%) of the liver, meat and heart tissue samples, respectively, were PCR-positive (Table 2 and Supplementary Fig. S1). The ELISA evaluation of 150 sera samples rendered $20(13.3 \%, 95 \%$ CI $9.3-17.4 \%)$ positive cases. On the other hand, in some sheep with positive ELISA results for blood sera, 6, 8, and 13 samples respectively from liver, meat, and heart also showed positive responses using the PCR method. Statistical analyses of the results showed a significant difference between positive results obtained from the serum ELISA and heart and meat PCR test results $(p<0.05)$. The agreement between ELISA and the heart and meat PCR tests was poor, where ELISA vs. heart PCR had a Kappa score of 0.24, and ELISA vs. meat PCR had a Kappa score of 0.21 . In contrast, the statistical analyses showed no significant difference between positive results of serum ELISA and liver PCR test $(\mathrm{p}>0.05)$. However, the agreement between ELISA and the liver PCR tests was shown by the Kappa test not to have consistency $(\kappa=0.13)$.
Table 2 Relationship between the results of ELISA and PCR of serum and tissue samples, respectively in sheep and goats

\begin{tabular}{|c|c|c|c|c|c|c|}
\hline \multirow[t]{2}{*}{ Ruminant } & & \multirow[t]{2}{*}{ Result } & \multicolumn{2}{|c|}{ Serum ELISA } & \multirow[t]{2}{*}{ No/total } & \multirow[t]{2}{*}{$\mathrm{p}$ value } \\
\hline & & & + & - & & \\
\hline \multirow[t]{6}{*}{ Sheep } & PCR on liver & + & 6 & 20 & $26 / 150$ & \\
\hline & & - & 14 & 110 & $124 / 150$ & 0.391 \\
\hline & PCR on meat & + & 8 & 25 & $33 / 150$ & \\
\hline & & - & 12 & 105 & $117 / 150$ & 0.049 \\
\hline & PCR on heart & + & 13 & 35 & $48 / 150$ & \\
\hline & & - & 7 & 95 & $102 / 150$ & 0.000 \\
\hline \multirow[t]{6}{*}{ Goats } & PCR on liver & + & 4 & 20 & $24 / 150$ & 0.215 \\
\hline & & - & 12 & 114 & $126 / 150$ & \\
\hline & PCR on meat & + & 3 & 23 & $26 / 150$ & \\
\hline & & - & 13 & 111 & $124 / 150$ & 0.132 \\
\hline & PCR on heart & + & 10 & 26 & $36 / 150$ & \\
\hline & & - & 6 & 108 & $114 / 150$ & 0.001 \\
\hline
\end{tabular}

No number of animals, PCR polymerase chain reaction, ELISA enzyme-linked immunosorbent 


\subsection{Serological and molecular evaluation in goat}

A total of $24(16 \%, 95 \%$ CI $12.5-19.6 \%), 26(17.3 \%, 95 \%$ CI 14.1-20.6\%) and 36 (24\%, 95\% CI 19.2-28.9\%) samples of liver, meat and heart tissues, respectively, showed positive results using PCR. The ELISA evaluation using 150 serum samples showed $16(10.6 \%, 95 \%$ CI $6.6-14.7 \%)$ positive cases (Table 2). On the other hand, in some goats that had positive ELISA results for blood sera, 4, 3, and 10 samples respectively from liver, meat, and heart showed positive results using the PCR method. Besides, statistical analyses of the results showed a significant difference between the positive results obtained from the serum ELISA and heart PCR tests $(\mathrm{p}<0.05)$. The agreement between ELISA and heart PCR tests was poor, where ELISA vs. heart PCR had a Kappa score of 0.28. In contrast, statistical analyses of the results revealed no significant difference between the positive results obtained from the serum ELISA and liver and meat PCR tests $(p>0.05)$. Also, the agreement between ELISA and the liver and meat PCR test results was without consistency, where ELISA vs. liver PCR had a Kappa score of 0.08, and ELISA vs. meat PCR had a Kappa score of 0.12.

Table 3 shows the results of the comparison of the molecular and serological evidence of various tissues (meat, heart, and liver) and blood samples of sheep and goats based on animal sex. From this observation, there was no statistically significant correlation $(p>0.05)$ between the infected tissues and the sex of both evaluated animals.

\section{Discussion}

Small ruminants such as sheep and goats are the main sources of meat for comestible consumption in Iran. These animals are also listed as suitable hosts for T. gondii (Schluter et al. 2014). In the current study, the presence of $T$.
gondii-IgG antibody and DNA of $T$. gondii were evaluated in randomly selected slaughtered animals. The percentage of positive samples of the $T$. gondii-IgG antibody was lower in comparison to the PCR results. The PCR can detect $T$. gondii DNA in both living and dead states of microorganisms, while the ELISA method detects only antibodies produced by the infected host (Liu et al. 2015). The ability of molecular methods is reported to be higher than that of serological methods for diagnosing T. gondii infection (Robert-Gangneux and Darde 2012; Martínez-Flores et al. 2017), which is in line with our results.

In previous studies in Ahvaz, T. gondii-IgG and IgM seropositivities were detected in 34.47 and $0.5 \%$ of healthy human blood donors, respectively (Saki et al. 2018). In another study, Mosallanejad et al. (2017) detected T. gondii- $I g G$ antibodies in $53.33 \%$ males and $46.66 \%$ females of stray cats in Ahvaz. Investigating the seroprevalence of $T$. gondii among women with abortion and women with typical delivery in Ahvaz, Iran, Saki et al. (2014) showed that the $\mathrm{IgG}$ antibodies were present in 24.6 and $21.5 \%$ of women with abortions and women with normal delivery, respectively. Likewise, the prevalence of $T$. gondii infection was observed to be $24.3 \%$ in women in Arak, Iran (Mohammadi et al. 2015). Interestingly, the detection of the T. gondii-IgG antibody in human blood has been significantly correlated with consuming undercooked liver, hamburger, and meat in these Iranian cites (Arbabi and Talari 2002; Mohammadi et al. 2015). Therefore, eating raw or undercooked meat and liver is known to be one of the major risk factors of toxoplasmosis worldwide (Andreoletti et al. 2007b; Mohammadi et al. 2015).

Furthermore, in this study, an in-house ELISA (90.1\% sensitivity and $85.9 \%$ specificity) designed for detecting the anti- $T$. gondii specific IgG in sera samples of sheep and goats revealed that 20 sheep (13.33\%) and 16 goats $(10.66 \%)$ had positive responses against $T$. gondii antigen.
Table 3 Serological and molecular comparison of Toxoplasma gondii infection in liver, meat, heart, and serum of sheep and goats

\begin{tabular}{|c|c|c|c|c|c|c|}
\hline \multirow[t]{4}{*}{ Organ/tissue } & \multicolumn{6}{|l|}{ Ruminant } \\
\hline & \multicolumn{3}{|l|}{ Sheep (no: 150 ) } & \multicolumn{3}{|l|}{ Goat (no: 150 ) } \\
\hline & Male (no: 75) & Female (no: 75) & $\mathrm{p}$ value & Male (no: 75) & Female (no: 75 ) & $\mathrm{p}$ value \\
\hline & Positive & Positive & & Positive & Positive Positive & \\
\hline Liver no. (\%) & $16(21.3 \%)$ & $10(13.3 \%)$ & 0.28 & $11(14.6 \%)$ & $13(17.3 \%)$ & 0.82 \\
\hline Total (no: 150) & & $26(17.3 \%)$ & & & $24(16 \%)$ & \\
\hline Meat no. (\%) & $13(17.3 \%)$ & $20(26.6 \%)$ & 0.23 & $9(12 \%)$ & $17(22.6 \%)$ & 0.13 \\
\hline Total (no: 150) & & $33(22 \%)$ & & & $26(17.3 \%)$ & \\
\hline Heart no. (\%) & $21(28 \%)$ & $27(36 \%)$ & 0.38 & $14(18.6 \%)$ & $22(29.3 \%)$ & 0.18 \\
\hline Total (no: 150) & & $48(32 \%)$ & & & $36(24 \%)$ & \\
\hline Serum no. $(\%)$ & $12(16 \%)$ & $8(10.6 \%)$ & 0.47 & $9(12 \%)$ & $7(9.3 \%)$ & 0.79 \\
\hline Total (no: 150) & & $20(13.3 \%)$ & & & $16(10.6 \%)$ & \\
\hline
\end{tabular}

no. number of animals 
In an eralier study, the seroprevalence of $T$. gondii in sheep using the Sabin-Feldman Dye Test was reported to be $62.2 \%, 39.3 \%$, and $15 \%$ in Roudsar, Masal, and Roudbar, three cities of Gilan province, Iran (Havakhah et al. 2014). Whereas, T. gondii seroprevalence in goats was $18.2 \%$ and $10 \%$ in Roudsar and Roudbar, respectively (Havakhah et al. 2014). In another epidemiologic study, detecting $T$. gondii infection via ELISA showed $41.51 \%, 22.72 \%$, and $18.03 \%$ positive responses in sheep slaughtered in three Iranian cities of Qazvin, Abyek, and Abhar, respectively (Izadyar et al. 2019). Using another approach, Sharif et al. (2007) evaluated a total of 290 cattle, 400 goats, and 588 sheep sera samples in different areas of Mazandaran province for the detection of antibodies against $T$. gondii by the indirect immunofluorescence antibody test (IFAT). Antibodies were found in 30\% of goats and 35\% of sheep. In other investigations using ELISA, anti- $T$. gondii $\operatorname{IgG}$ was detected in $12.2 \%$ of sheep and $4.4 \%$ of goat sera samples in Kashan, Iran (Rasti et al. 2017). Based on the results of liver juice serology, $32.6 \%$ and $48 \%$ of sheep and goats, respectively, showed antibodies against $T$. gondii (Bahrami et al. 2019).

Accordingly, based on the results of these studies, the rate of $T$. gondii infection in sheep and goats is in a range of $10-38 \%$ in different regions of Iran (Table 1). Though toxoplasmosis is an important cause of abortion in sheep and goats (Dubey et al. 1980; Edwards and Dubey 2013), infection in fetoplacental tissues due to congenital toxoplasmosis appears to be more prevalent in aborted fetuses of sheep in Iran (Danehchin et al. 2016). As for other countries, the seroprevalence rate of $T$. gondii in sheep and goats was reported to be $47.8 \%$ and $40.5 \%$ in Brazil (Rego et al. 2016), $28.6 \%$ and $27.5 \%$ in Italy (Gazzonis et al. 2020), 15.2\% and $17.9 \%$ in USA (Rani et al. 2020), and $33.6 \%$ and $18.5 \%$ in Portugal (Lopes et al. 2013), respectively, and $11.9 \%$ in goats in Algeria (Dubey et al. 2020). In addition, the prevalence of
T. gondii DNA in goats was reported 5.2\% in China (Qian et al. 2020).

The differences between the findings of the current study and those of some previous studies are presumed to be related to factors such as climate, animal age, the abundance of cats in the livestock breeding area, husbandry conditions, sample size/type, and serology test. Overall, there are four main climates in Iran, including mild and wet, hot and dry, cold and mountainous, and also warm and humid (Mizani et al. 2017; Sharif et al. 2015). The mild and wet climate is the most suitable condition for the lifecycle of $T$. gondii, especially for the maturation of oocysts and their transmission to a new host (Havakhah et al. 2014; Mizani et al. 2017). As for its climatic conditions, Ahvaz is located in the southeast region of the country, covering an area of about $815 \mathrm{~km}^{2}$, and has a subtropical hot desert climate with extremely hot summers and short winters (Fig. 1) (Ahvaz climate 2020).

The source of livestock slaughtered in Ahvaz slaughterhouses is variable as most ranchers provide livestock from different cities of Khuzestan province or even neighboring provinces (e.g., Ilam, Lorestan, Chaharmahal and Bakhtiari, and Kohgiluyeh and Boyer-Ahmad) that have rich pastures (Fig. 1). Traditionally, most ranchers still use outdoor farms for rearing their livestock as a common method of grazing livestock in Iran. However, the lack of adequate control over pastures in traditional livestock breeding (outdoor farms) compared to the specific and controlled pastures (indoor farms) is believed to be an important risk factor for animal infection with cat feces containing $T$. gondii oocysts (Sharif et al. 2015; Shapiro et al. 2019). Likewise, Izadyar et al. (2019) maintained that many domestic and stray cats living in the livestock breeding area are considered as the main risk factor for $T$. gondii infection in livestock. These are probably the underlying reasons for the differences between our results and those of Bahrami et al. (2019) in Ahvaz.
Fig. 1 Iran map: KHUZESTAN (a) and AHVAZ (b)

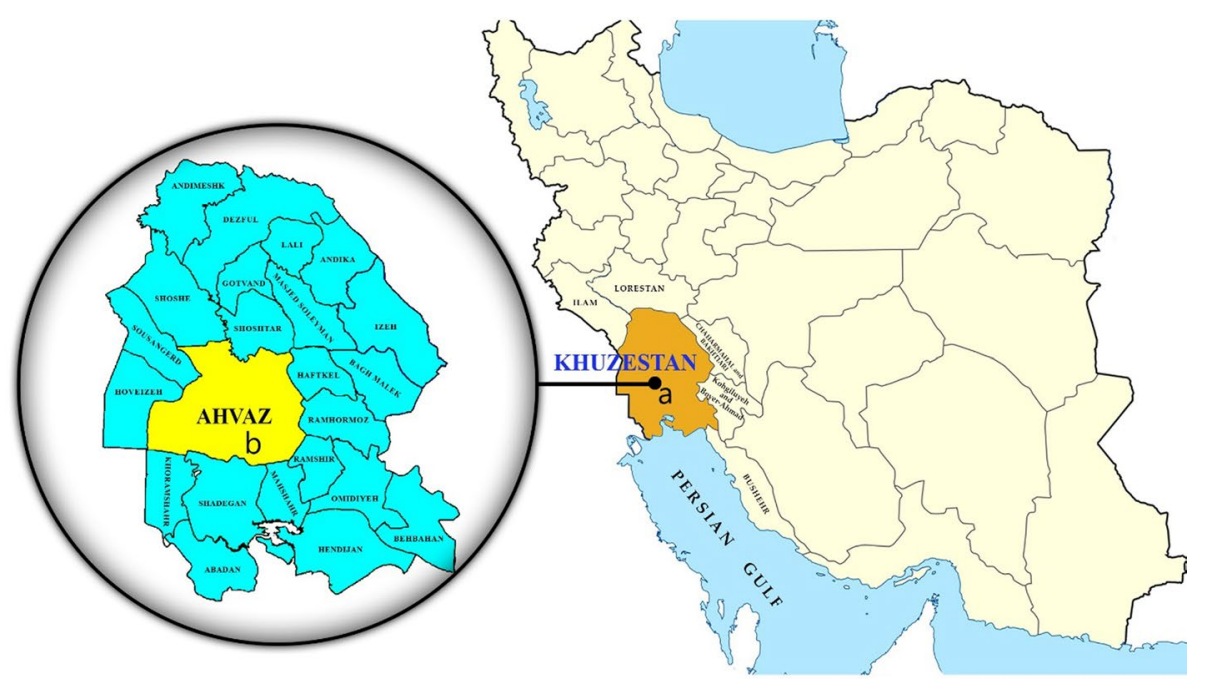


Furthermore, Bahrami et al. (2019) collected livestock samples during almost three seasons of the year (i.e., autumn, winter, and spring), whereas in the current study samples were only collected during autumn. Therefore, the samples of Bahrami et al. (2019) could be more diverse compared to ours, which, in turn, could lead to the reduced infection rate in their study. Generally, as far as the season of the year was concerned, the number of cats shedding $T$. gondii oocysts in the autumn was reported to be significantly higher than that in other seasons which seems to be the most important risk factor for livestock infection when grazing in pastures (Herrmann et al. 2010; Schares et al. 2016).

With regard to the climatic condition as one the main reasons for the prevalence of toxoplasmosis, the highest prevalence rate of $T$. gondii has been observed in the northern regions of Iran with a humid climate (Sharif et al. 2015; Havakhah et al. 2014). As such, the parasite's oocysts can remain infective in a humid climate, and consequently the risk of infection in ruminants such as goats and sheep increases due to livestock grazing on the fodder infected with parasitic oocysts (Robert-Gangneux and Darde 2012; Katzer et al. 2011). The prevalence rates of $T$. gondii in the current study in Ahvaz were found to be lower in comparison with those in other regions of Iran with a humid climate. We infer that our results are influenced by climate conditions given that the neighboring provinces supplying livestock for slaughter in Ahvaz have mostly arid climate conditions. In contrast, in the north of Iran, especially in Gilan and Mazandaran provinces with humid climates, higher seroprevalence rates of $T$. gondii are reported in sheep and goats (Havakhah et al. 2014; Sharif et al. 2007). However, a low seroprevalence rate of antibodies to Toxoplasma gondii in sheep and goats is reported in Kashan, in the center of Iran (12.2\% and 4.4\%), and Kerman in the southeastern part of the country (3.3\% and 1.7\%) with arid climates (Derakhshan and Mousavi, 2014; Rasti et al. 2017) (see details in Table 1).

Parasite burden is another important factor for detecting the protozoa in tissue samples using molecular methods. However, its role in the discrepancy observed between our results and the findings of Bahrami et al. (2019) is not verifiable here. On the other hand, the types of samples used for the ELISA test were different in the two studies, as Bahrami et al. (2019) used liver juice, while in the current study sera were used. The concentration of antibody sources may also be involved [1/100 sera in the present study and $1 / 10$ in the study of Bahrami et al. (2019)]. As reported elsewhere, there is a good correlation between the ELISA results of the anti-T. gondii antibodies detected in meat juices and serum samples (Lundén et al. 2002; Wingstrand et al. 1997; Opsteegh et al. 2016). In the current study, an ELISA test designed by Bahrami et al. (2019) for detecting the anti- $T$. gondii specific IgG in sheep and goat blood was used. It seems that the levels of anti-T. gondii specific IgG are lower in liver juice compared to the serum, and to compensate this, a higher dilution was used for the sera samples. Based on the approach described by Wingstrand et al. (1997) who found excellent correlations between $T$. gondii antibody levels of meat juice and serum, serum samples were 10 times more diluted than meat juice samples.

Based on the results of the present study, the highest percentage of positive samples in sheep was observed in their heart muscles $(32 \%)$, followed by meat $(22 \%)$, and liver $(17.3 \%)$ tissue samples. Moreover, the percentage of positive heart samples was found to be slightly lower than the infection rate of $34.32 \%$ reported by another study performed on heart and diaphragm tissues in Jahrom (Armand et al. 2016). The percentage of positive heart samples identified in the current study is also lower than the results obtained from a study in three provinces located in Eastern Iran; namely Kerman, Razavi Khorasan, and South Khorasan (52.5\%) (Tavakoli Kareshk et al. 2017), while it is higher than the rates reported from Kashan (17.8\%) (Rasti et al. 2017). Likewise, the percentage of positive meat samples in sheep with T. gondii in the current study was lower compared to the findings of Azizi et al. (2014) in Chaharmahal and Bakhtiari on femur muscle (28\%), while it was higher than the retainers' meat, including heart, meat, and tongue (14\%) reported in Ahvaz (Rahdar et al. 2012). Besides, the percentage of positive liver samples in the present study was found to be lower than the results obtained in Chaharmahal and Bakhtiari (30\%) (Azizi et al. 2014), whereas it was higher than the findings (8\%) reported by Bahrami et al. (2019) in Ahvaz within 6 months (December 2016-May 2017).

According to the results of the current study, the highest percentage of positive samples in goats was observed in the heart (24\%), followed by meat (17.3\%) and liver (16\%) tissue samples. In addition, the percentage of positive heart samples reported here is higher than the infection rate reported in Kashan (17.8\%) (Rasti et al. 2017), and almost equal or slightly higher than the infection rate (22\%) obtained from three eastern provinces of Kerman, Razavi Khorasan, and South Khorasan (Tavakoli Kareshk et al. 2017). Likewise, the percentage of positive liver samples in the present study is higher than the results (11.3\%) reported by Bahrami et al. (2019) in Ahvaz.

It has been observed in experimental studies on rodents and small ruminants that the parasite load in different tissues may vary depending on the time since infection. Indeed, parasite load is high in the brain, liver, and blood only at the onset, and it increases in the heart and skeletal muscles over time (Juránková et al. 2014; Dadimoghaddam et al. 2014). According to our findings, the reason for high infection rate in heart and meat tissues compared to the liver can be the time of infection. As such, one may hypothesize that in sheep and goat muscles, the $T$. 
gondii load increases over time. Following local infection, skeletal muscle cells are capable of actively participating in the local immune response and can express a variety of immune factors, including classical and non-classical major histocompatibility complex molecules, co-stimulatory molecules, and adhesion factors as well as cytokines and chemokines (Wiendl et al. 2005). It should be maintained that differences in the distribution of cysts in different tissues of the host carcass may also depend on infection parameters, such as the parasite strain or the infective stage (oocysts or bradyzoites) (Swierzy et al. 2014). Thus, the factors mentioned above could be the possible reasons for the lower risk of infection in the meat than the heart.

Generally, our findings are in line with the overall results of studies conducted so far in Iran, estimating the infection rate of T. gondii to be $27 \%$ and $31 \%$ in goats and sheep, respectively (Sharif et al. 2015). Although the prevalence of $T$. gondii infection in sheep and goats is variable across the world, the existing higher prevalence recorded in sheep compared to the goats is consistent with the general values reported in previous studies that considered both species reared in the same areas (Rasti et al. 2017; Gazzonis et al. 2020; Hashemi-fesharki 1996; Van der Puije et al. 2000; Tzanidakis et al. 2012; GarciaBocanegra et al. 2013; Lopes et al. 2013). Besides, sheep can develop very high levels of $T$. gondii antibodies during acute infection, and high IgG antibodies can, in turn, persist for months or years (Dubey and Beattie 1988). It seems that possible reasons for the higher infection rate of sheep compared to goats are the feeding type and grazing time. Goats are quite agile compared to sheep, frequently using particular plants and plant parts, such as leaves and twigs of woody plant species, whereas sheep usually graze plants on the ground and their grazing time is longer than goats. Additionally, outdoor sheep are exposed to soil and water, which are potential sources of $T$. gondii infection (Webster et al. 2013). Therefore, due to the time and type of grazing of livestock, sheep are more exposed to consume parasite cysts and, consequently more often infected than goats (Animut and Goetsch 2008).

In this study, the evaluation of the diagnostic efficiency of PCR in comparison to in-house ELISA revealed that PCR yielded marginally higher diagnostic efficiency compared to ELISA. Table 2 presents the results of serum ELISA and tissue sample PCR in sheep and goats. Recent infection with no previous exposure may explain negative ELISA samples with positive PCR results (Saki et al. 2018). Also, the distribution of $T$. gondii parasites within the same tissue is uneven, and parasite density may be low. Therefore, a negative result has to be interpreted carefully given that the parasites could be located in the unexamined parts of the target tissue. This explanation can also be considered for positive ELISA samples with negative PCR results.
As for the limitation of this study, not enough information was available on the exact age of animals at the time of slaughter. Generally, sheep of different ages are slaughtered for human consumption in Iran. Likewise, the slaughtered animals in this study were randomly selected from animals aged 6-60 months (Kavari et al. 2013; Armand et al. 2016). According to the study of Armand et al. (2016), in sheep at the age of 24-60 months, PCR-positive samples (diaphragm and heart) were higher than those in serum ELISA results. In other epidemiologic studies, $T$. gondii seroprevalence in sheep aged 2-5 years was significantly higher than that in sheep $<2$ years (Katzer et al. 2011; Abdallah et al. 2019). This may indicate that the age of sheep in the current study was $>2$ years, which has probably influenced the molecular and serological results obtained.

Goats of different age groups are likewise slaughtered for human consumption. According to Kavari et al. (2013), the seroprevalence of $T$. gondii in goats was high in all age groups, but the highest rate occurred in 1.5- to 2.5-year-old goats (Kavari et al. 2013). In another epidemiologic study, $T$. gondii seroprevalence in goats $>5$ years old was significantly higher than that in other age groups (Abdallah et al. 2019). This may indicate that the prevalence of infection can be variable in different age groups.

Consistent with some other investigations, the present study reports a higher percentage of positive samples in sheep than goats (Tavakoli Kareshk et al. 2017; Sharif et al. 2015). Moreover, according to some reports, there is no significant correlation between animal sex and infection rate (Tavakoli Kareshk et al. 2017; Armand et al. 2016). However, a significant relationship was reported between the infection rate and sex in animals in some other studies (Asgari et al. 2011). Concerning the sex risk factor, the findings of the current study showed that the percentage of positive samples in both animal species was higher in females than in males. This finding is in line with the results of Asgari et al. (2011) showing a significant relationship between infection and sex in livestock, as the infection rate in females was higher than in males (Jokelaniena et al. 2010; Asgari et al. 2011; Khamesipour et al. 2010; Armand et al. 2016), probably due to lower immunological resistance in females (Guimarães et al. 2013). Moreover, the stress of lactation and pregnancy reduces the effectiveness of the immune system, and subsequently increases the risk of infection in female livestock (Dubey et al. 1998; Tilahun et al. 2018).

\section{Conclusion}

Based on the findings of the present study, sheep and goats could be important sources of T. gondii infection in Ahvaz, Iran. Given that these animals are the main sources of meat 
and liver consumption in the whole country including Ahvaz, it is thus recommended that people at risk, especially pregnant women, consume well-done livestock organs, especially the liver which is traditionally consumed half-cooked or rare, so as to prevent infection with $T$. gondii.

Acknowledgements This research received no specific funding.

\section{Compliance with ethical standards}

Conflict of interest The authors declare that they have no conflict of interest.

\section{References}

Abdallah MC, Kamel M, Benfodil Karima B, Ansel Samir A, Khelef Djamel K, Rachid K, Khatima AQ (2019) Cross-sectional survey on Toxoplasma gondii infection in cattle, sheep, and goats in Algeria: seroprevalence and risk factors. Vet Sci 6:63. https://doi. org/10.3390/vetsci603006

Ahmed H, Malik A, Arshad M, Mustafa I, Riaz Khan M, Afzal MS, Ali S, Mobeen M, Simsek S (2016) Seroprevalence and spatial distribution of Toxoplasmosis in sheep and goats in North-Eastern region of Pakistan. Korean J Parasitol 54(4):439-446. https://doi. org/10.3347/kjp.2016.54.4.439

Ahvaz climate (2020) Ahvaz climate Iran. Iran Meteorological Organization publishing Ahvaz climate. https://en.wikipedia.org/wiki/ Ahvaz. Accessed 27 Mar 2020

Andreoletti O, Budka H, Buncic S, Colin P, Collins DJ, De Koeijer A, Griffin J, Havelaar A, Hope J, Klein G, Kruse H, Magnino H, López AM, McLauchlin J, Nguyen-Thé C, Noeckler K, Noerrung B, Maradona MP, Roberts T, Vågsholm I, Vanopdenbosch E (2007a) Scientific opinion of the panel on biological hazards on a request from EFSA on surveillance and monitoring of Toxoplasma in humans, foods and animals. EFSA J 583:1-64. https:// doi.org/10.2903/j.efsa.2007.583

Andreoletti O, Budka H, Buncic S, Colin P, Collins DJ, De Koeijer A, Griffin J, Havelaar A, Hope J, Klein G, Kruse H, Magnino H, López AM, McLauchlin J, Nguyen-Thé C, Noeckler K, Noerrung B, Maradona MP, Roberts T, Vågsholm I, Vanopdenbosch E (2007b) Surveillance and monitoring of Toxoplasma in humans, food and animals scientific opinion of the panel on biological hazards. EFSA J 583:1-64. https://doi.org/10.2903/j.efsa.2007.583

Animut G, Goetsch AL (2008) Co-grazing of sheep and goats: benefits and constraints. Small Rumin Res 77:127-145

Arbabi M, Talari SA (2002) The prevalence of Toxoplasmosis in subjects involved in meat industry and pregnant women in Kashan. KAUMS J (FEYZ) 6:28-38

Armand B, Solhjoo K, Shabani-Kordshooli M, Davami MH, Sadeghi M (2016) Toxoplasma infection in sheep from south of Iran monitored by serological and molecular methods; risk assessment to meat consumers. Vet World 9:850-855. https://doi.org/10.14202 /vetworld.2016.850-855

Asgari Q, Sarnevesht J, Kalantari M, Sadat SJA, Motazedian MH, Sarkari B (2011) Molecular survey of Toxoplasma infection in sheep and goat from Fars province, Southern Iran. Trop Anim Health Prod 43:389-392. https://doi.org/10.1007/s1125 0-010-9704-1

Azizi H, Shiran B, Boroujeni AB, Jafari M (2014) Molecular survey of Toxoplasma gondii in sheep, cattle and meat products in Chaharmahal va Bakhtiari province, Southwest of Iran. Iran J Parasitol 9:429-434
Bahrami S, Zarei M, Ghorbanpour M, Karami S (2019) Toxoplasma gondii in sheep and goat livers: risks for human consumption. J Hell Vet Med Soc 70:1387-1392. https://doi.org/10.12681/jhvms .20344

Dadimoghaddam Y, Daryani A, Sharif M, Ahmadpour E, Hossienikhah Z (2014) Tissue tropism and parasite burden of Toxoplasma gondii RH strain in experimentally infected mice. Asian Pac J Trop Med 7(7):521-524

Danehchin L, Razmi G, Naghibi A (2016) Isolation and genotyping of Toxoplasma gondii strains in ovine aborted fetuses in Khorasan Razavi Province, Iran. Korean J Parasitol 54(1):15-20. https://doi. org/10.3347/kjp.2016.54.1.15

Daryani A, Sarvi S, Aarabi M, Mizani A, Ahmadpour E, Shokri A, Rahimi MT, Sharif M (2014) Seroprevalence of Toxoplasma gondii in the Iranian general population: a systematic review and meta-analysis. Acta Trop 137:185-194. https://doi.org/10.1016/j. actatropica.2014.05.015

Derakhshan M, Mousavi M (2014) Serological survey of antibodies to Toxoplasma gondii in cats, goats, and sheep in Kerman, Iran. Comp Clin Path 23:267-268

Dubey JP (2008) The history of Toxoplasma gondii-the first 100 years. J Eukaryot Microbiol 55:467-475. https://doi.org/10.111 1/j.1550-7408.2008.00345.x

Dubey JP (2009) Toxoplasmosis in sheep-the last 20 years. Vet Parasitol 163:1-14. https://doi.org/10.1016/j.vetpar.2009.02.026

Dubey JP, Beattie CP (1988) Toxoplasmosis of animals and man. CRC Press, Boca Raton

Dubey J, Sharma S, Lopes C, Williams J, Williams C, Weisbrode S (1980) Caprine toxoplasmosis: abortion, clinical signs, and distribution of Toxoplasma in tissues of goats fed Toxoplasma gondii oocysts. Am J Vet Res 41:1072-1076

Dubey JP, Romand S, Hilali M, Kwok OCH, Thulliez P (1998) Seroprevalence of antibodies to Neospora caniuum and Toxoplasma gondii in water buffaloes (Bubalus bubalis) from Egypt. Int J Parasitol 28:527-529. https://doi.org/10.1016/S0020-7519(97)00190 $-2$

Dubey JP, Murata FHA, Cerqueira-Cézar CK, Kwok OCH (2020) Public health and economic importance of Toxoplasma gondii infections in goats: the last decade. Res Vet Sci 132:292-307. https:// doi.org/10.1016/j.rvsc.2020.06.014

Edwards JF, Dubey J (2013) Toxoplasma gondii abortion storm in sheep on a Texas farm and isolation of mouse virulent atypical genotype $T$. gondii from an aborted lamb from a chronically infected ewe. Vet Parasitol 192(1):129-136. https://doi.org/10.1016/j.vetpa r.2012.09.037

Garcia-Bocanegra I, Cabezon O, Hernandez E, Martinez-Cruz MS, Martinez-Moreno A, Martinez-Moreno J (2013) Toxoplasma gondii in ruminant species (cattle, sheep, and goats) from Southern Spain. J Parasitol 99(3):438-440. https://doi.org/10.1645/12-27.1

Gazzonis AL, Zanzani SA, Villa L, Manfredi MT (2020) Toxoplasma gondii infection in meat-producing small ruminants: meat juice serology and genotyping. Parasitol Int 76:102060. https://doi. org/10.1016/j.parint.2020.102060

Guimarães LA, Bezerra RA, De Rocha DS, Albuquerque GR (2013) Prevalence and risk factors associated with anti-Toxoplasma gondii antibodies in sheep from Bahia state, Brazil. Rev Bras Parasitol Veterinária 22:220-224. https://doi.org/10.1590/S1984-29612 013000200041

Hajimohammadi B, Eslami G, Khalatbari-limaki S, Ehrampoush MH, Oryan A, Zandi H, Dehghan HR (2017) The role of Linguatula serrata nymph in transmission of enteric bacterial pathogens to internal organs in sheep. J Parasit Dis 41(3):754-760. https://doi. org/10.1007/s12639-017-0884-8

Hashemi-fesharki R (1996) Seroprevalence of Toxoplasma gondii in cattle, sheep and goats in Iran. Vet Parasitol 61:1-3. https://doi. org/10.1016/0304-4017(95)00818-7 
Havakhah Y, Rastaghi E, Reza A, Amiri S, Babaie J, Aghighi Z, Golkar M (2014) Prevalence of Toxoplasma gondii in sheep and goats in three counties of Gilan Province, North of Iran the more humid climate the higher prevalence. J Med Microbiol Infect Dis 2:80-83

Herrmann DC, Pantchev N, Vrhovec MG, Barutzki D, Wilking H, Fröhlich A, Lüder CG, Conraths FJ, Schares G (2010) Atypical Toxoplasma gondii genotypes identified in oocysts shed by cats in Germany. Int J Parasitol 40:285-292. https://doi.org/10.1016/j. ijpara.2009.08.001

Hillyer GV, Soler de Galanes M, Rodriguez-Perez J, Bjorland J, Silva de Lagrava M, Ramirez Guzman S, Bryan RT (1992) Use of the Falcon assay screening test-enzyme-linked immunosorbent assay (FAST-ELISA) and the enzyme-linked immunoelectrotransfer blot (EITB) to determine the prevalence of human fascioliasis in the Bolivian Altiplano. Am J Trop Med Hyg 46:603-609

Izadyar N, Nikfarjam BA, Rastaghi ARE, Alizadeh SA, Heydarian P, Saraei M (2019) A serologic study on Toxoplasma gondii infection in slaughtered sheep and goats in Qazvin Province, Iran. Trop Anim Health Prod 51:1289-1293. https://doi.org/10.1007/s1125 0-019-01832-2

Jalal S, Nord CE, Lappalainen M, Evengård B (2004) Rapid and sensitive diagnosis of Toxoplasma gondii infections by PCR. Clin Microbiol Infect 10:937-939. https://doi.org/10.111 1/j.1469-0691.2004.00948.x

Jittapalapong S, Sangvaranond A, Pinyopanuwat N, Chimnoi W, Khachaeram W, Koizumi S, Maruyama S (2005) Seroprevalence of Toxoplasma gondii infection in domestic goats in Satun Province, Thailand. Vet Parasitol 127:17-22. https://doi.org/10.1016/j. vetpar.2004.08.019

Jokelainena P, Näreahoa A, Knaapia S, Oksanenb A, Rikulac U, Sukuraa A (2010) Toxoplasma gondii in wild cervids and sheep in Finland: North-south gradient in seroprevalence. Vet Parasitol 171:331-336. https://doi.org/10.1016/j.vetpar.2010.04.008

Juránková J, Basso W, Neumayerová H, Baláž V, Jánová E, Sidler X, Deplazes P, Koudela B (2014) Brain is the predilection site of Toxoplasma gondii in experimentally inoculated pigs as revealed by magnetic capture and real-time PCR. Food Microbiol 38:167-170

Katzer F, Brülisauer F, Collantes-Fernández E, Bartley PM, Burrells A, Gunn G, Stephen W, Maley SW, Cousens C, Innes EA (2011) Increased Toxoplasma gondii positivity relative to age in 125 Scottish sheep flocks; evidence of frequent acquired infection. Vet Res 41:121

Kavari A, Nowzari N, Jula FM, Hashemzadeh FH (2013) A serological and molecular study on Toxoplasma gondii infection in sheep and goat in Tabriz. Arch Razi Inst 68(1):29-35. https://doi. org/10.7508/ARI.2013.01.005

Khamesipour F, Doosti A, Mobarakeh HI, Komba EVG (2010) Toxoplasma gondii in cattle, camels and sheep in Isfahan and Chaharmahal va Bakhtiary Provinces, Iran. Jundishapur J Microbiol 7(6):e17460. https://doi.org/10.5812/jjm.17460

Liu Q, Wang ZD, Huang SY, Zhu XQ (2015) Diagnosis of toxoplasmosis and typing of Toxoplasma gondii. Parasite Vector 8:292. https ://doi.org/10.1186/s13071-015-0902-6

Lopes AP, Dubey JP, Neto F, Rodrigues A, Martins T, Rodrigues M, Cardoso L (2013) Seroprevalence of Toxoplasma gondii infection in cattle, sheep, goats and pigs from the North of Portugal for human consumption. Vet Parasitol 193(1-3):266-269. https://doi. org/10.1016/j.vetpar.2012.12.001

Lundén A, Lind P, Engvall EO, Gustavsson K, Uggla A, Vågsholm I (2002) Serological Survey of Toxoplasma gondii in pigs slaughtered in Sweden. Scand J Infect Dis 34:362-365. https://doi. org/10.1080/00365540110080205

Mahboub HD, Helal MA, Eldaim MAA, El-Razek EMA, Elsify AM (2013) Seroprevalence of abortion causing agents in Egyptian sheep and goat breeds and their effects on the animal's performance. J Agric Sci 5:9. https://doi.org/10.5539/jas.v5n9p92
Martínez-Flores WA, Palma-García JM, Caballero-Ortega H, Del Viento-Camacho A, López-Escamilla E, Martínez-Hernández F, Maravilla P (2017) Genotyping Toxoplasma gondii with the B1 gene in naturally infected sheep from an endemic region in the pacific coast of Mexico. Vector Borne Zoonotic Dis 17:495502. https://doi.org/10.1089/vbz.2016.2085

Mizani A, Alipour A, Sharif M, Sarvi S, Amouei A, Shokri A, Rahimi MT, Hosseini SA, Daryani A (2017) Toxoplasmosis seroprevalence in Iranian women and risk factors of the disease: a systematic review and meta-analysis. Trop Med Health 45:7. https://doi.org/10.1186/s41182-017-0048-7

Mohammadi A, Saeedeh Shojaee S, Salami M, Zareei M, Mohebali M, Keshavarz H (2015) Seroepidemiological study of Toxoplasmosis in women referred to arak marriage consulting center during 2012-2013. Iran J Public Health 44(5):654-658

Mosallanejad B, Hamidinejat H, Seifiabad Shapouri MR, Rezaei Ghaleh F (2017) A comparison between serological and molecular tests in diagnosis of Toxoplasma gondii infection among stray cats in Ahvaz, southwestern Iran. Arch Razi Inst 72(2):105-112. https://doi.org/10.22092/ARI.2017.109841

Naing L, Winn T, Rusli B (2006) Practical issues in calculating the sample size for prevalence studies. AOS 1:9-14

Opsteegh M, Maas M, Schares G, Giessen JVD, Conraths F, Bangoura B, Blaga R, Boireau P, Vallee I, Djokic V, Roux DL, Perret-Duménil C, Ducry T, Wisselink H, Cornelissen J, Villena I, Aubert D, Györke A, Cozma V, Mircean V, Paştiu AI, Balea A, Kalmar Z, Bărburaș D, Pozio E, Spano F, Limon G, Georgiev M, Blake D, Guitian J, Dominguez J, Katzer F, Burrells A, Innes L, Djurkovic-Djakovic O, Klun I (2016) Relationship between seroprevalence in the main livestock species and presence of Toxoplasma gondii in meat (GP/EFSA/BIOHAZ/2013/01) An extensive literature review. Final report. EFSA supporting publication EN-996

Petrie A, Watson P (1999) Statistics for veterinary and animal science. Blackwell Science Ltd, Londra

Qian W, Yan W, Lv C, Bai R, Wang T, Wei Z, Zhang M (2020) Molecular detection and genotyping of Toxoplasma gondii and Neospora caninum in slaughtered goats in Central China. Foodborne Pathog Dis 17(5):348-356. https://doi.org/10.1089/fpd.2019.2726

Rahdar M, Samarbaf-Zadeh A, Arab L (2012) Evaluating the prevalence of Toxoplasma gondii in meat and meat products in Ahvaz by PCR method. Jundishapur J Microbiol 5:570-573. https://doi. org/10.5812/jjm.4280

Rahdar M, Samarbaf-Zadeh A, Arab L (2014) Evaluating the prevalence of Toxoplasma gondii in meat and meat 281 products in Ahvaz by PCR method. Jundishapur J Microbiol 5:570-573. https ://doi.org/10.5812/jjm.428

Rani S, Cerqueira-Cezar CK, Murata FHA, Kwok OCH, Dubey JP, Abani K, Pradhan AK (2020) Distribution of Toxoplasma gondii tissue cysts in shoulder muscles of naturally infected goats and lambs. J Food Prot 83(8):1396-1401

Rasti S, Marandi N, Abdoli A, Delavari M, Mousavi SGA (2017) Serological and molecular detection of Toxoplasma gondii in sheep and goats in Kashan, Central Iran. J Food Saf 38:e12425. https:// doi.org/10.1111/jfs. 12425

Rego WMF, Paula NRO, Vitor RWA, Silva RAB, Diniz BLM, Sousa MM, Cardoso JFS (2016) Risk factors for Toxoplasma gondii infection in goats and sheep raised in the State of Piauí in northeast Brazil. Small Rumin res 141:17-23. https://doi.org/10.1016/j. smallrumres.2016.04.010

Robert-Gangneux F, Darde ML (2012) Epidemiology of and diagnostic strategies for toxoplasmosis. Clin Microbiol Rev 25:264-296. https://doi.org/10.1128/CMR.05013-11

Saki J, Mohammadpour N, Moramezi F, Khademvatan S (2014) Seroprevalence of Toxoplasma gondii in women who have aborted in comparison with the women with normal 
delivery in Ahvaz, Southwest of Iran. Sci World J. https://doi. org/10.1155/2015/764369

Saki J, Foroutanb M, Khodkara I, Khodadadic A, Nazarid L (2018) Seroprevalence and molecular detection of Toxoplasma gondii in healthy blood donors in southwest Iran. Transfus Apheres Sci 58(1):79-82. https://doi.org/10.1016/j.transci.2018.12.003

Schares G, Ziller M, Herrmann DC, Globokar MV, Pantchev N, Conraths FJ (2016) Seasonality in the proportions of domestic cats shedding Toxoplasma gondii or Hammondia hammondi oocysts is associated with climatic factors. Int J Parasitol 46(4):263-273. https://doi.org/10.1016/j.ijpara.2015.12.006

Schluter D, Däubener W, Schares G, Groß U, Pleyer U, Luder C (2014) Animals are key to human toxoplasmosis. Int J Med Microbiol 304:917-929. https://doi.org/10.1016/j.ijmm.2014.09.002

Shaapan RM (2016) The common zoonotic protozoal diseases causing abortion. J Parasit Dis 40:1116-1129. https://doi.org/10.1007/ s12639-015-0661-5

Shapiro K, Bahia-Oliveira L, Dixon B, Dumètre A, de Wit LA, Elizabeth I (2019) Environmental transmission of Toxoplasma gondii: Oocysts in water, soil and food. Food Waterborne Parasitol. https ://doi.org/10.1016/j.fawpar

Sharif M, Gholami SH, Ziaei H, Daryani A, Laktarashi B, Ziapour SP, Vahedi M (2007) Seroprevalence of Toxoplasma gondii in cattle, sheep and goats slaughtered for food in Mazandaran province, Iran, during 2005. Vet J 174:422-424. https://doi.org/10.1016/j. tvj1.2006.07.004

Sharif M, Sarvi S, Shokri A, Hosseini Teshnizi S, Rahimi MT, Mizani A, Daryani A (2015) Toxoplasma gondii infection among sheep and goats in Iran: a systematic review and meta-analysis. Parasitol Res 114:1-16. https://doi.org/10.1007/s00436-014-4176-2

Swierzy IJ, Muhammad M, Kroll J, Abelmann A, Tenter AM, Lüder CGK (2014) Toxoplasma gondii within skeletal muscle cells: a critical interplay for food-borne parasite transmission. Int J Parasitol 44:91-98

Tavakoli Kareshk A, Mahmoudvand H, Keyhani A, Tavakoli OR, Mohammadi MA, Babaei Z, Zia-Ali N (2017) Molecular detection and genetic diversity of Toxoplasma gondii in different tissues of sheep and goat in Eastern Iran. Trop Biomed 34:681-690
Tenter AM, Heckeroth AR, Weiss LM (2000) Toxoplasma gondii: from animals to humans. Int J Parasitol 30:1217-1258. https:// doi.org/10.1016/s0020-7519(00)00124-7

Tilahun B, Tolossa YH, Tilahun G, Ashenafi H, Shimelis S (2018) Seroprevalence and risk factors of Toxoplasma gondii infection among domestic ruminants in East Hararghe Zone of Oromia Region, Ethiopia. Vet Med Int 144(1):64-71. https://doi. org/10.1155/2018/4263470

Tzanidakis N, Maksimov P, Conraths FJ, Kiossis E, Brozos C, Sotiraki S, Schares G (2012) Toxoplasma gondii in sheep and goats: seroprevalence and potential risk factors under dairy husbandry practices. Vet Parasitol 190(3-4):340-348. https://doi.org/10.1016/j. vetpar.2012.07.020

Van der Puije WN, Bosompem KM, Canacoo EM, Wastling JM, Akanmori BD (2000) The prevalence of anti-Toxoplasma gondii antibodies in Ghanaian sheep and goats. Acta Trop 76:21-26. https ://doi.org/10.1016/s0001-706x(00)00084-x

Webster JP, Kaushik M, Bristow GC, McConkey GA (2013) Toxoplasma gondii infection, from predation to schizophrenia: can animal behaviour help us understand human behaviour? J Exp Biol 216:99-112. https://doi.org/10.1242/jeb.074716

Wiendl H, Hohlfeld R, Kieseier BC (2005) Immunobiology of muscle: advances in understanding an immunological microenvironment. Trends Immunol 26:373-380

Wingstrand A, Lind P, Haugegaard J, Henriksen SA, Bille-Hansen V, Sørensen V (1997) Clinical observations, pathology, bioassay in mice and serological response at slaughter in pigs experimentally infected with Toxoplasma gondii. Vet Parasitol 72:129-140. https ://doi.org/10.1016/s0304-4017(97)00034-4

Publisher's Note Springer Nature remains neutral with regard to jurisdictional claims in published maps and institutional affiliations. 